Jurnal Media Komunikasi Pendidikan Pancasila dan Kewarganegaraan

Volume 2, Nomor 1 April 2020

\title{
PELAKSANAAN PEMBINAAN NARAPIDANA DALAM MENCEGAH RESIDIVISME DI LEMBAGA PEMASYARAKATAN KELAS II B CILACAP
}

\author{
Debi Romala Putri
}

Fakultas Hukum, Universitas Wijayakusuma Purwokerto

Ikama Dewi Setia Triana

Fakultas Hukum, Universitas Wijayakusuma Purwokerto

\begin{abstract}
To find out the implementation of prisoners ' construction in preventing the resistance in the correctional Institution class II B Cilacap and to know the obstacles factors in the implementation of prisoners 'construction. To achieve these goals the authors use the method of normative juridical approach, the specification of the research is qualitative descriptive. Data presentation method presented in the form of writing that will then be processed and analyzed. Based on the discussion on the results of the research, it can be concluded: there is no difference of coaching conducted to build a regular or a resident convict in the Correctional Institution class II B Cilacap. Coaching is more focused on coaching that is self-reliance and personality. But in its implementation is appropriate and meets the rules of Law No. 12 of 1995 on correctional, government regulation of the Republic of Indonesia number 31 year 1999 on coaching and mentoring the correctional community and has Observe the rights of the target citizens in accordance with government regulation of the Republic of Indonesia No. 32 year 1999 on terms and procedure for implementing the rights of the target citizens. The implementation inhibitory factor is differentiated into internal factors and external factors. Internal factor is the personnel/apparatus of correctional Institution, financial administration and physical facilities. While the external factors are the stigmatisation of society, Human resources, marketing of limited skills, funds, members of the community have not received the presence of ex-convicts in their environment, and there is not available employment for ex-convicts.
\end{abstract}

Keywords: residivisme, prisoner building, and Correctional Institution

\begin{abstract}
Abstrak
Untuk mengetahui pelaksanaan pembinaan narapidana dalam mencegah residivisme di Lembaga Pemasyarakatan Kelas II B Cilacap serta mengetahui faktor-faktor hambatan dalam pelaksanaan pembinaan narapidana. Untuk mencapai tujuan tersebut penulis menggunakan metode pendekatan Yuridis Normatif, Spesifikasi Penelitian adalah Deskriptif Kualitatif. Metode penyajian data disajikan dalam bentuk tulisan yang kemudian akan diolah dan dianalisis. Berdasarkan pembahasan terhadap hasil penelitian, maka dapat disimpulkan: Tidak ada perbedaan pembinaan yang dilakukan untuk membina narapidana biasa maupun residivis di Lembaga Pemasyarakatan Kelas II B Cilacap. Pembinaan lebih difokuskan kepada pembinaan yang bersifat kemandirian dan kepribadian. Namun dalam pelaksanaannya telah sesuai dan memenuhi aturan Undangundang Nomor 12 Tahun 1995 Tentang Pemasyarakatan, Peraturan Pemerintah Republik Indonesia Nomor 31 Tahun 1999 Tentang Pembinaan dan Pembimbingan Warga Binaan Pemasyarakatan dan telah memperhatikan hak Warga Binaan sesuai dengan Peraturan Pemerintah Republik Indonesia Nomor 32 Tahun 1999 Tentang Syarat dan Tata Cara
\end{abstract}


Pelaksanaan Hak Warga Binaan. Adapun faktor penghambat pelaksanaan pembinaan dibedakan menjadi faktor internal dan faktor eksternal. Faktor internal adalah personil/ aparat pembina Lembaga Pemasyarakatan, administrasi keuangan dan sarana fisik. Sedangkan faktor eksternal adalah stigmatisasi masyarakat, sumber daya manusia, pemasaran hasil ketrampilan yang terbatas, dana, anggota masyarakat belum menerima kehadiran mantan narapidana di lingkungannya, dan belum tersedia lapangan pekerjaan bagi bekas narapidana.

Kata Kunci : residivisme, pembinaan narapidana, dan lembaga pemasyarakatan

\section{Pendahuluan}

Dalam era globalisasi seperti sekarang ini, kejahatan merupakan bagian tak terpisahkan dari kehidupan manusia. Kejahatan sebagai salah satu bentuk masalah sosial merupakan sebuah kenyataan yang harus dihadapi oleh setiap lapisan masyarakat. Perkembangan kejahatan bukanlah suatu hal yang asing, oleh karena sejarah kehidupan manusia sejak awal diciptakan telah terbukti mengenal kejahatan. Apalagi pada saat seperti sekarang ini perkembangan ilmu pengetahuan dan teknologi justru memberi peluang yang lebih besar bagi berkembangnya berbagai bentuk kejahatan.

Van Bammelen merumuskan kejahatan adalah tiap kelakuan yang bersifat tidak susila dan merugikan, dan menimbulkan begitu banyak ketidaktenangan dalam suatu masyarakat tertentu, sehingga masyarakat itu berhak untuk mencelanya dan menyatakan penolakannya atas kelakuan itu dalam bentuk nestapa dengan sengaja diberikan karena kelakuan tersebut. $^{1}$

Kejahatan memiliki sifat yang merugikan masyarakat karena termasuk tindakan yang melanggar norma, moral dan hukum yang berlaku. Masyarakat sudah terbiasa atau dibiasakan, memandang pelaku sebagai satu-satunya faktor dalam gejala kejahatan. Hal ini yang mendasari upaya penanganan kejahatan masih terfokus hanya pada tindakan penghukuman terhadap pelaku.

Pentingnya penegakan hukum dalam mengatasi berbagai jenis kejahatan tidak dapat dipungkiri lagi. Karena tujuan hukum yang paling bersahaja ialah bahwa hukum itu diadakan supaya terjaga ketenteraman di dalam suatu masyarakat. ${ }^{2}$

Talcoot Parsons mengemukakan bahwa fungsi utama dari suatu sistem hukum adalah melakukan fungsi integratif yaitu mengurangi konflikkonflik dan melancarkan proses interaksi pergaulan sosial. ${ }^{3}$ Pemerintah melalui aparat penegak hukum berusaha menanggulangi gangguan-gangguan dari berbagai tindak kejahatan. Pelaksanaan pembinaan pada narapidana dalam upaya mengembalikan narapidana menjadi masyarakat yang baik sangatlah penting dilakukan, tidak hanya bersifat material atau sprititual saja, melainkan keduanya harus berjalan dengan seimbang, ini merupakan hal-hal pokok yang menunjang narapidana mudah
Dwi Yani, "Definisi Arti Kejahatan", diakses dari https://hukum-dan-

umum.blogspot.com/2012/04/definisi-arti-

kejahatan.html, pada tanggal 27 September pukul 13.45

\footnotetext{
Iswanto, Pengantar Ilmu Hukum (Purwokerto: UNIVERSITAS JENDRAL SOEDIRMAN, 2013), hlm.36. Ronny Hanitiyo Soemitro, Studi Hukum dan Masyarakat (Bandung: Alumni,1982), hlm. 34.
} 
dalam menjalani kehidupannya setelah selesai menjalani masa pidana. ${ }^{4}$

Pembinaan di dalam lembaga pemasyarakatan diharapkan mampu membentuk kepribadian serta mental narapidana yang dianggap tidak baik di mata masyarakat menjadi berubah ke arah yang seutuhnya dan sesuai dengan norma serta hukum yang berlaku. Proses pelaksanaan yang dilakukan di Lembaga Pemasyarakatan atau yang disebut LAPAS melalui suatu pembinaan dan bimbingan dianggap mencerminkan bahwa Negara Indonesia adalah negara yang menghargai dan menjunjung tinggi hak asasi manusia. Sebagaimana tercantum dalam penjelasan atas Undang-Undang Nomor 12 Tahun 1995 Tentang Pemasyarakatan, yang menyebutkan Sistem pemasyarakatan diselenggarakan dalam rangka membentuk warga binaan pemasyarakatan agar menjadi manusia seutuhnya, menyadari kesalahan, memperbaiki diri, dan tidak mengulangi tindak pidana sehingga dapat diterima kembali oleh lingkungan masyarakat, dapat aktif berperan dalam pembangunan, dan dapat hidup secara wajar sebagai warga yang baik dan bertanggung jawab. Lembaga pemasyarakatan sebagai ujung tombak pengayoman membuka jalan bagi perlakukan terhadap narapidana dengan cara sistem pemasyarakatan sebagai tujuan pidana penjara dan juga menjadi cara untuk membimbing dan membina. Dalam perlakuan terhadap narapidana, adalah melakukan pembinaan agar narapidana mejadi manusia yang berguna di masa mendatang. Programprogram pembinaan yang teratur dan disusun secara matang serta dilaksanakan dengan penuh kesadaran

\footnotetext{
Erina Suhestia Ningtyas," Pelaksanaan Program Pembinaan Narapidana Pada Lembaga Pemasyarakatan Dalam Rangka Pengembangan
}

serta kelayakan akan menjamin integritas sistem pemasyrakatan. Namun dalam implementasi di lembaga pemasyarakatan saat ini, bahwa apa yang digariskan dalam Undang-Undang tentang Pemasyarakatan hanyalah sebatas harapan belaka yang tidak terealisasikan, karena berbagai fakta justru menunjukkan gambaran sebaliknya. Buruknya manajemen lembaga pemasyarakatan di Indonesia dapat dilihat dari kompleksitas permasalahan yang terjadi.

Hal tersebut ditandai dengan munculnya penjahat yang tergolong sebagai residivis, yaitu penjahat yang mengulangi kejahatan yang sama setelah menjalani pidana. Berdasarkan ketentuan Pasal 486 KUHP residivis dapat diancam pidana sepertiga lebih berat dari ancaman pidana yang normal dengan catatan bahwa perbuatan yang jenisnya sama tersebut ia lakukan dalam waktu kurang dari 5 tahun setelah menjalani pidana yang dijatuhkan.

Pengulangan tindak pidana bukan hal yang baru dalam dunia hukum, karena dimana ada kejahatan di situ pula ada pengulangan kejahatan dan pengulangan kejahatan dianggap sebagai penerusan dari niat jahat sebagaimana dikemukakan oleh Bartolus seorang ahli hukum, bahwa "Humanum enimest peccare, angilicum, secemendare, diabolicum perseverare" atau kejahatan dan pengulangan kejahatan dianggap sebagai penerusan dari niat jahat, maka dapat dipastikan bahwa praktik pengulangan kejahatan itu sendiri sama tuanya dengan praktik kejahatan. ${ }^{5}$

Kondisi inilah yang menjadi tantangan besar bagi lembaga pemasyarakatan untuk melakukan pembinaan dalam upaya mengendalikan

Sumber Daya Manusia", Jurnal Administrasi Publik (JAP), Vol. 1, No. 6, Hal. 1266-1275 | 1266

Abidin Zainal Farid, Hukum Pidana 1, (Jakarta: Sinar Grafika, 1995), hlm.432. 
terjadinya residivis, karena lembaga pemasyarakatan selalu mendapat berbagai macam hambatan dalam mencapai sasaran tujuan pembinaan narapidana.

Berkaitan dengan uraian tersebut, penulis tertarik melakukan penelitian dan menyusunnya dalam sebuah skripsi dengan judul: "Pelaksanaan Pembinaan Narapidana Dalam Mencegah Residivisme Di Lembaga Pemasyarakatan Kelas II B Cilacap”.

\section{Rumusan Masalah}

1. Apakah pelaksanaan pembinaan narapidana dalam mencegah residivisme di Lembaga Pemasyarakatan Kelas II B Cilacap sudah sesuai dengan peraturan perundang-undangan yang berlaku ?

2. Faktor apa sajakah yang menjadi penghambat serta pendukung yang dihadapi oleh Lembaga Pemasyarakatan Kelas II B Cilacap dalam melakukan pembinaan narapidana?

\section{Metodologi Penelitian}

1. Metode Pendekatan

Metode pendekatan yang digunakan dalam penelitian ini adalah yuridis normatif. Penelitian hukum secara yuridis maksudnya penelitian yang mengacu pada studi kepustakaan yang ada ataupun terhadap data sekunder yang digunakan. Sedangkan normatif maksudnya penelitian hukum yang bertujuan untuk memperoleh pengetahuan tentang penerapan di dalam prakteknya.

2. Lokasi Penelitian

Penelitian ini akan dilaksanakan di Kabupaten Cilacap Jawa Tengah, tepatnya di Lembaga Pemasyarakatan Kelas II B Cilacap Jalan Mataram 1.

3. Sumber Data

Jenis dan sumber data yang penulis gunakan dalam penelitian ini terdiri atas 2 (dua), yaitu: a. Data Primer, yaitu bahan hukum atau data yang sudah tersedia sehingga peneliti hanya mencari dan mengumpulkan penulisan (data yang diperoleh dari buku-buku, internet, undang-undang dan peraturan pemerintah yang terkait).

b. Data sekunder, yaitu data yang diperoleh dari wawancara dengan pihak terkait sehubungan dengan penelitian ini.

4. Metode Pengumpulan Data

Metode pengumpulan data yang penulis lakukan terbagi atas 2 (dua), yakni:

a. Metode wawancara, yaitu mengumpulkan data secara langsung melalui tanya jawab berdasarkan daftar pertanyaan yang telah disiapkan dan melakukan wawancara tidak terstruktur untuk memperoleh data dan informasi yang diperlukan.

b. Metode studi pustaka, yaitu suatu teknik pengumpulan data dengan mempergunakan dokumen-dokumen, catatan-catatan, laporan-laporan, dan bahan-bahan yang relevan dengan permasalahan yang dibahas.

5. Metode Penyajian data

Metode penyajian data dalam pembuatan laporan hasil penelitian adalah penyajian data dalam bentuk tulisan. Data yang terkumpul akan diolah dan dianalisis.

6. Metode Analisis Data

Setelah semua data terkumpul, maka data tersebut akan diolah dan dianalisis secara deskriptif kualitatif yaitu dengan cara menyelaraskan dan menggambarkan keadaan yang nyata mengenai pelaksanaan pembinaan narapidana. Hasil inventarisasi dan wawancara tersebut kemudian diolah dan dianalisis secara kualitatif untuk menghasilkan data yang bersifat deskriptif.

\section{Hasil Dan Pembahasan Hasil Penelitian}


Lembaga Pemasyarakatan (Lapas) Kelas II B Kabupaten Cilacap merupakan salah satu unit pelaksana teknis (UPT) pemasyarakatan sebagai tempat pembinaan narapidana yang bernaung di bawah kantor wilayah departemen hukum dan HAM provinsi Jawa Tengah yang mempunyai fungsi membina, keamanan dan merawat warga binaan.

Sejarah Lapas Kelas II B Kabupaten Cilacap adalah peninggalan jaman Belanda pada tahun 1887, pada tahun 1985 dengan keputusan Menteri Kehakiman No: M.04.PR.07.03 tahun 1985 difungsikan sebagai Rutan Kelas II B Cilacap dan pada tanggal 16 April 2003 dengan keputusan Menteri Kehakiman No: 05.PR.07.03 tahun 2003 status Rutan diubah menjadi Lapas Kelas II B Cilacap.

Lembaga Pemasyarakatan Kelas II B Cilacap berlokasi di Jalan Mataram 1, hingga 10 Desember 2019 tercatat jumlah narapidana di Lembaga Pemasyarakatan Kabupaten Cilacap mencapai 465 narapidana/tahanan. Padahal daya tampung (kapasitas) Lapas kelas II B Cilacap hanya mencapai 254. Gambaran infrastruktur Lapas Kelas II B Cilacap, tanah milik terdiri dari:

$$
\text { 1. Luas tanah Lapas Jalan }
$$
Mataram $1 \quad: 5.520 \mathrm{~m}^{2}$

2. Perumahan Dinas

$$
\text { : } 9 \text { unit }
$$

3. Luas Bangunan

$$
\text { : } 4.284 \mathrm{~m}^{2}
$$

Memiliki sarana fisik sebagai berikut:
1. Kantor
: $1758.67 \mathrm{~m}^{2}$
2. Kamar Hunian$$
\text { : } 1542.33 \mathrm{~m}^{2}
$$
$3 . \quad$ Aula
: $95 \mathrm{~m}^{2}$
4. Dapur
: $147 \mathrm{~m}^{2}$
5. Bengkel Kerja
: $90 \mathrm{~m}^{2}$

$$
\begin{aligned}
& \text { 6. } \quad \text { Masjid } \\
& : 229 \mathrm{~m}^{2}
\end{aligned}
$$

Tiap blok hunian dilengkapi dengan fasilitas seperti lahan untuk pertamanan, ruang tidur, kamar mandi dan we dan juga sel pengasingan.

Struktur organisasi Lembaga Pemasyarakatan Kelas II B Cilacap terdiri dari beberapa bagian yang masing-masing mempunyai tugas dan fungsi yang berbeda-beda. Struktur organisasi Lembaga Pemasyarakatan Kelas II B Cilacap adalah sebagai berikut:

1. Kepala Lembaga Pemasyarakatan

2. Kepala Sub. Bagian Tata Usaha

3. Kepala Urusan Umum

4. Kepala Urusan Kepegawaian dan $\mathrm{KU}$

5. Kepala Satuan Pengamanan Lapas

6. Kepala Seksi Binadik dan Giatja

7. Kepala Seksi Administrasi Kamtib

8. Kepala Sub. Seksi Perawatan

9. Kepala Sub. Seksi Kegiatan Kerja

10. Kepala Sub. Seksi Registrasi dan Bimkemas

11. Kepala Sub. Seksi Keamanan

12. Kepala Sub. Seksi Pelaporan dan Tata Tertib

13. Petugas Pengamanan

Pada saat ini total jumlah pegawai Lembaga Pemasyarakatan Kelas II B Cilacap sebanyak 60 orang terdiri dari:

1. Tingkat Pendidikan:

a. Strata $2(\mathrm{~S} 2) \quad$ : 2 orang

b. $\quad$ Strata $1(\mathrm{~S} 1) \quad$ : 24 orang

c. Sarjana Muda (D3) : 1 orang

d. SLTA : 33 orang

e. SLTP : - orang

2. Tenaga Medis:

a. Dokter umum

Puskesmas Cilacap Tengah

b. Dokter gigi

Puskesmas Cilacap Tengah 
c. Perawat

Pegawai Lapas Cilacap

3. Personil Keamanan:

a. Staff KPLP : 1 orang

b. Regu pengamanan : 29 orang terbagi 4 regu

Dalam menjaga keamanan dan ketertiban di dalam Lapas dilaksanakan oleh Kesatuan Pengamanan Lembaga Pemasyarakatan (KPLP) yang dipimpin oleh Ka.KPLP dilengkapi dengan sarana dan prasarana pengamanan. Sarana prasarana pengamanan terdiri dari:

1. Senjata api

2. Metal detector

3. Borgol

4. Handy talky

5. Tongkat kejut

6. Borgol renteng

7. CCTV

Untuk lebih jelasnya, di bawah ini akan penulis kemukakan hasil observasi mengenai keadaan pada umumnya di Lembaga Pemasyarakatan KeIas II B Cilacap dalam kaitannya dengan pembinaan narapidana adalah sebagai berikut:

1. Lembaga Pemasyarakatan Kelas II B Cilacap pada umumnya terlihat rapi dilihat dari susunan bangunan yang teratur karena telah mengalami rehabilitasi serta kebersihannya cukup terjamin.

2. Kamar tidur, jumlah kamar tidur yang tersedia di Lembaga Pemasyarakatan Kelas II Cilacap terdiri dari beberapa blok yang meliputi kamarkamar terdiri dari 32 kamar dan masingmasing terdiri tempat tidur dan satu kamar mandi di dalamnya. Kemudian terdapat pula 2 sel pengasingan (isolasi) untuk narapidana yang melanggar tata tertib.

3. Kamar mandi atau WC dapat dikatakan cukup baik, karena luasnya cukup memadai dan terletak dibagian pojok kamar masing-masing. Sedangkan kamar mandi luar terdapat 2 di bagian blok selatan.

4. Dapur dengan peralatannya cukup baik, luas dan cukup bersih.

5. Ruang bimbingan kerja tempatnya cukup luas dengan peralatan di dalamnya berupa mesin-mesin pemotong kayu dan juga terdapat ruang menjahit dilengkapi dengan mesin jahit.

6. Sarana olahraga terdiri dari tennis, volley, sepak bola, tennis meja dan bulu tangkis.

7. Tempat ibadah terdiri dari masjid dan gereja.

8. Pangkas rambut dipergunakan untuk narapidana yang akan melakukan potong rambut.

9. Perpustakaan untuk kegiatan membaca, hanya saja fungsi dari perpustakaan ini belum optimal dikarenakan jumlah buku yang ada belum terlalu lengkap. Diperkirakan dalam tahun 2020 fungsi perpustakaan akan optimal karena pihak Lapas akan bekerja sama dengan Dinas Kearsipan Perpustakaan Lingkup Jawa Tengah.

Sebelum narapidana pembinaan, pertama-tama diawali oleh suatu proses penelitian dan pendataan yang meliputi:

1. Data pribadi

2. Riwayat hidup sosial

3. Pelanggaran-pelanggaran yang dilakukannya

4. Kecakapan suatu bakat rokhani dan jasmaninya

5. Sifat kepribadiannya

Bentuk pembinaan secara umum dapat dikelompokan dalam dua macam, yaitu: 1. Pembinaan kemandirian

Pembinaan kemandirian adalah pembinaan yang ditujukan terhadap jasmani narapidana, agar kelak pada saat mereka selesai menjalankan masa pidananya telah betul-betul siap menjadi anggota masyarakat yang baik. Adapun bentuk pembinaan kemandirian yaitu:
a. Pertukangan kayu
b. Jahitan 
c. Batik ecoprint

d. Kaligrafi

e. Perikanan

f. Perkebunan

g. Kerajinan tas rajut

2. Pembinaan kepribadian berkaitan erat dengan daya cipta, rasa, kesusilaan, kejujuran dan sopan santun. Adapun bentuk dapat berupa:

a. Pembinaan rohani

b. Pembinaan kesadaran berbangsa dan bernegara

c. Pembinaan jasmani

d. Penyuluhan hukum

e. Tim pengamat pemasyarakatan

f. Kunjungan keluarga

g. Pembinaan integrasi

h. Kesenian

i. Keorganisasian

Di samping dua macam bentuk pembinaan tersebut masih pula disertai dengan fasilitas lain yang dirasakan sebagai penunjang, adapun berupa:

1. Fasilitas sandang

2. Fasilitas pangan

3. Fasilitas perawatan kesehatan

4. Fasilitas rekreasi dan olahraga

\section{Pembahasan}

1. Pelaksanaan Pembinaan Narapidana Dalam Mencegah Residivisme

Lembaga pemasyarakatan merupakan lembaga terakhir dalam Sistem Peradilan Pidana. Lembaga pemasyarakatan berfungsi sebagai tempat pelaksanaan pembinaan narapidana dengan harapan agar narapidana dapat memperbaiki diri dan tidak mengulangi tindak kejahatan (residivis) sehingga dapat diterima kembali oleh masyarakat. Pembinaan merupakan inti dari sistem pemasyarakatan karena bertujuan mengembangkan fungsi sosialnya dengan rasa tanggung jawab agar dapat menyesuaikan diri dalam masyarakat. Penulis mengelompokan pelaksanaan pembinaan narapidana di Lembaga
Pemasyarakatan ke dalam dua jenis pelaksanaan pembinaan, yaitu:

a. Pelaksanaan Pembinaan

Narapidana Secara Yuridis

Pembinaan narapidana di Lembaga Pemasyarakatan Kelas II B Cilacap pada dasarnya masih mengacu pada pembinaan narapidana pada umumnya. Menurut Undang-undang Nomor 12 Tahun 1995 Tentang Pemasyarakatan yang menyebutkan bahwa:

Pasal 1 UU No. 12 Tahun 1995

(1)"Pemasyarakatan adalah kegiatan untuk melakukan pembinaan Warga Binaan Pemasyarakatan berdasarkan sistem, kelembagaan, dan cara pembinaan yang merupakan bagian akhir dari sistem pemidanaan dalam tata peradilan pidana."

(2)“'Sistem Pemasyarakatan adalah suatu tatanan mengenai arah dan batas serta cara pembinaan Warga Binaan Pemasyarakat berdasarkan Pancasila yang dilaksanakan secara terpadu antara Pembina, yang dibina, dan masyarakat untuk meningkatkan kualitas Warga Binaan Pemasyarakatan agar menyadari kesalahan, memperbaiki diri, dan tidak mengulangi tindak pidana sehingga dapat diterima kembali oleh lingkungan masyarakat, dapat aktif berperan dalam pembangunan, dan dapat hidup secara wajar sebagai warga yang baik dan bertanggung jawab."

Sedangkan dalam Peraturan Pemerintah Republik Indonesia Nomor 31 Tahun 1999 Tentang Pembinaan dan Pembimbingan Warga Binaan Pemasyarakatan menyebutkan bahwa:

Pasal 1 PP No. 31 Tahun 1999

(1)"Pembinaan adalah kegiatan untuk meningkatkan kualitas ketaqwaan kepada Tuhan Yang Maha Esa, intelektual, sikap dan perilaku, profesional, kesehatan jasmani dan rohani Narapidana dan Anak Didik Pemasyarakatan.” 
(2)“"Pembimbingan adalah pemberian tuntutan untuk meningkatkan kualitas ketaqwaan terhadap Tuhan Yang Maha Esa, intelektual, sikap dan perilaku, profesional, kesehatan jasmani dan rohani Klien Pemasyarakatan".

(9)“'Asimilasi adalah proses pembinaan Narapidana dan Anak Didik Pemasyarakatan yang dilaksanakan dengan membaurkan Narapidana dan anak Didik Pemasyarakatan data kehidupan masyarakat."

Dalam Peraturan Pemerintah Republik Indonesia Nomor 32 Tahun 1999 Tentang Syarat Dan Tata Cara Pelaksanaan Hak Warga Binaan Pemasyarakatan menyebutkan bahwa: Pasal 1 PP No. 32 Tahun 1999

(2)"Pembinaan adalah kegiatan untuk meningkatkan kualitas ketaqwaan kepada Tuhan Yang Maha Esa, intelektual, sikap dan perilaku, profesional, kesehatan jasmani dan rohani Narapidana dan Anak Didik Pemasyarakatan."

(3)" Pendidikan dan pengajaran adalah usaha sadar untuk menyiapkan Warga Binaan Pemasyarakatan melalui kegiatan bimbingan atau latihan bagi peranannya di masa yang akan datang." (5)"Pembimbingan adalah pemberian tuntunan untuk meningkatkan kualitas ketaqwaan terhadap Tuhan Yang Maha Esa, intelektual, sikap dan perilaku, profesional, kesehatan jasmani dan rohani Klien Pemasyarakatan."

Program pembinaan dan pembimbingan juga telah diatur di dalam Pasal 2 ayat 1 dan Pasal 3 Peraturan Pemerintah Republik Indonesia Nomor 31 Tahun 1999 Tentang Pembinaan dan Pembimbingan Warga Binaan Pemasyarakatan yang menyebutkan bahwa:

Pasal 2 ayat 1 PP No. 31 Tahun 1999
(1)"Program
pembinaan
dan
pembimbingan
meliputi kegiatan

pembinaan dan pembimbingan kepribadian dan kemandirian."

Pasal 3 PP No. 31 Tahun 1999

Pembinaan dan pembimbingan kepribadian dan kemandirian sebagaimana dimaksud dalam Pasal 2 meliputi hal-hal yang berkaitan dengan:

a. ketaqwaan kepada Tuhan Yang Maha Esa;

b. kesadaran berbangsa dan bernegara;

c. intelektual;

d. sikap dan perilaku;

e. kesehatan jasmani dan rohani;

f. kesadaran hukum;

g. reintegrasi sehat dengan masyarakat;

h. ketrampilan kerja; dan

i. latihan kerja dan produksi.

Namun dalam pelaksanaan program pembinaan dan pembimbingan kepribadian dan kemandirian, juga harus tetap menjamin terpenuhinya hak-hak narapidana. Hak narapidana diatur dalam Bab II Peraturan Pemerintah Republik Indonesia Nomor 32 Tahun 1999 Tentang Syarat dan Tata Cara Pelaksanaan Hak Warga Binaan Pemasyarakatan. Pada bagian pertama dijelaskan tentang hak ibadah setiap narapidana, yang menyebutkan bahwa:

Pasal 2 ayat 1 PP No. 32 Tahun 1999

(1)" Setiap Narapidana dan Anak Didik Pemasyarakatan berhak untuk melakukan ibadah sesuai dengan agama dan kepercayaannya."

Tentang hak mendapat perawatan rohani dan jasmani diatur dalam pasal 5, yang menyebutkan bahwa:

Pasal 5 PP No. 32 Tahun 1999

Setiap Narapidana dan Anak Didik Pemasyarakatan berhak mendapat perawatan rohani dan jasmani.

Perawatan rohani dan jasmani yang dimaksud dalam Pasal 5 berupa pemberian kesempatan melakukan olahraga dan rekreasi. Pengaturan hak pemberian upah dan premi terhadap 
narapidana diatur dalam bagian ke tujuh Pasal 29, yang menyebutkan bahwa:

Pasal 29 PP No. 32 Tahun 1999

(1)"Setiap Narapidana yang bekerja berhak mendapat upah atau premi."

Sedangkan untuk pengaturan hak tentang kunjungan diatur pada bagian ke delapan Pasal 30, yang menyebutkan bahwa:

Pasal 30 PP No. 32 Tahun 1999

(1)"Setiap Narapidana dan Anak Didik Pemasyarakatan berhak menerima kunjungan dari keluarga, penasihat hukum, atau orang tertentu lainnya."

b. Pelaksanaan Pembinaan

Narapidana Secara Sosiologis

Secara umum tidak ada perbedaan mekanisme pembinaan narapidana biasa dengan narapidana residivis di Lembaga Pemasyarakatan Kelas II B Cilacap. Sistem pemasyarakatan dalam pembinaan narapidana di Lembaga Pemasyarakatan Kelas II B Cilacap disesuaikan dengan proses dan tahap pembinaan yang telah direncanakan. Adapun tujuan pembinaan adalah untuk membentuk Warga Binaan Pemasyarakatan agar menjadi manusia seutuhnya, menyadari kesalahannya, memperbaiki diri, dan tidak mengulangi tindak pidananya lagi, sehingga dapat diterima kembali oleh lingkungan masyarakat, dan dapat berperan aktif dalam pembangunan serta hidup wajar sebagai warga yang baik dan bertanggung jawab. Untuk mencapai tujuan tersebut, narapidana diwajibkan untuk mengikuti program-program pembinaan yang telah ditetapkan di Lembaga Pemasyarakatan Kelas II B Cilacap sejak mereka masuk sampai bebas dari Lapas.

Pemenuhan hak-hak narapidana selama berada di dalam Lembaga Pemasyarakatan Kelas II B Cilacap juga menurut penulis telah sesuai dengan Peraturan Pemerintah Nomor 32 Tahun 1999. Pemenuhan hak narapidana dalam hal beribadah, dapat diketahui berdasarkan hasil penelitian bahwa di dalam Lembaga Pemasyarakatan Kelas II B Cilacap telah disediakan masjid untuk sarana beribadah narapidana beragama Islam dan gereja untuk narapidana beragama Kristen. Pemberian hak dalam hal perawatan rohani dan jasmani juga didapatkan narapidana di dalam Lembaga Pemasyarakatan Kelas II B Cilacap. Hak perawatan rohani dan jasmani yang dimaksud adalah dalam hal pemenuhan fasilitas rekreasi dan olahraga. Untuk menghindari kejenuhan narapidana, maka narapidana diperbolehkan melakukan kesenian seperti bernyanyi bersama menggunakan gitar, sedangkan sarana olahraga tersedia walaupun hanya terbatas di dalam lingkungan Lapas. Hak pemberian upah dan premi juga didapatkan narapidana. Narapidana yang bekerja di bagian produksi karya di program kemandirian yang telah disediakan oleh Lembaga Pemasyarakatan Kelas II B Cilacap akan diberikan upah sesuai dengan peraturan yang berlaku. Upah atau premi didapatkan dari hasil penjualan karya, yang selanjutnya akan dibagi dan dikumpulkan oleh petugas. Hasil upah atau premi yang terkumpul akan diserahkan setelah narapidana bebas dari Lapas. Sedangkan untuk pemenuhan hak narapidana yang berupa kunjungan keluarga juga terpenuhi. Kunjungan keluarga sendiri merupakan bagian dari program pembinaan kepribadian di dalam Lembaga Pemasyarakatan Kelas II B Cilacap. Sesuai dengan fungsi pemasyarakatan adalah memulihkan hubungan antara narapidana dengan keluarga maupun masyarakat. Pemenuhan hak tersebut sangat penting untuk diberikan dengan tujuan agar narapidana tidak merasa terisolasi dari lingkungan keluarga maupun masyarakat. 
Program pembinaan kepribadian dan kemandirian yang dilaksanakan di Lembaga Pemasyarakatan Kelas II B Cilacap juga telah sesuai dengan Pasal 3 Peraturan Pemerintah Republik Indonesia Nomor 31 Tahun 1999. Sesuai dengan hasil penelitian yang dilakukan oleh penulis bahwa program kepribadian sendiri mencakup pembinaan rohani, pembinaan kesadaran berbangsa dan bernegara, pembinaan jasmani, penyuluhan hukum sampai pelatihan keorganisasian dilakukan. Sedangkan program pembinaan kemandirian disediakan dari mulai pertukangan kayu sampai pembuatan kerajinan tas rajut untuk narapidana wanita.

2. Faktor Penghambat dan Pendukung Pelaksanaan Pembinaan Narapidana Dalam Mencegah Residivisme

Lembaga Pemasyarakatan Kelas II B Cilacap sebagai unit pelaksanaan pembinaan narapidana dalam sistem pemasyarakatan, telah mengupayakan beberapa faktor penunjang kearah pembinaan atau pelaksanaan sistem pemasyarakatan sebagaimana yang diharapkan. Adapun faktor penunjang yang berupa fasilitas tersebut dapat diuraikan sebagai berikut:

a. Faktor penunjang sarana fisik Keberadaan sarana fisik yang berupa bangunan Lembaga Pemasyarakatan, khususnya tidak terlepas dari tempat dan kedudukan serta sejarah terbentuknya.

b. Faktor penunjang non fisik

1) Aparat/ Petugas Lembaga Pemasyarakatan

2) Narapidana

3) Faktor Perundang-undangan

Namun dalam penerapannya selalu diikuti dengan persoalan-persoalan yang dapat menjadi hambatan dalam pelaksanaan pembinaan. Adapun hal-hal yang menjadi penghambat adalah:
a. Personil/Aparat Pembina
Lembaga Pemasyarakatan

1) Kurangnya jumlah pembina sehingga menimbulkan perbandingan yang mencolok.

2) Kurangnya tenaga ahli di Lembaga Pemasyarakatan Kelas II B Cilacap.

b. Administrasi keuangan

c. Sarana fisik

d. Hambatan di luar Lapas:

1) Stigmatisasi masyarakat

2) Sumber daya manusia

3) Pemasaran hasil ketrampilan yang terbatas

4) Dana

5) Anggota masyarakat belum menerima kehadiran mantan narapidana di lingkungannya

6) Belum tersedia lapangan pekerjaan bagi bekas narapidana

Setelah mengetahui beberapa hambatan dalam pelaksanaan pembinaan narapidana, maka dalam rangka turut serta mensukseskan Sistem Pemasyarakatan, Lembaga Pemasyarakatan Kelas II B Cilacap telah melakukan usaha-usaha untuk mengatasi kendala dalam pelaksanaan Sistem Pemasyarakatan yang integratif terhadap narapidana, antara lain dalam hal pelaksanaan pembinaan terhadap narapidana, Lapas membentuk forum kerja sama dengan instansi-instansi terkait, antara lain dengan Departemen Agama yaitu dalam hal pembinaan mental narapidana. Dengan Dinas Kearsipan Perpustakaan Lingkup Jawa Tengah dalam hal melengkapi buku yang ada di perpustakaan Lapas. Dengan Istana Figura Cilacap sebagai pihak ke 3 yang menyediakan bingkai sehingga mendukung nilai jual karya lukis kaligrafi Warga Binaan Pemasyarakatan.

\section{Kesimpulan}

Berdasarkan hasil penelitian dari pembahasan, maka penulis menyimpulkan di antaranya sebagai berikut: 
Pelaksanaan pembinaan narapidana yang dilakukan Lembaga Pemasyarakatan kelas II B Cilacap dapat disimpulkan bahwa tidak ada perbedaan pembinaan yang dilakukan untuk narapidana biasa maupun residivis. Pembinaan lebih difokuskan kepada pembinaan yang bersifat kemandirian dan kepribadian. Namun dalam pelaksanaannya telah sesuai dan memenuhi aturan Undang-undang Nomor 12 Tahun 1995 Tentang Pemasyarakatan, Peraturan Pemerintah Republik Indonesia Nomor 31 Tahun 1999 Tentang Pembinaan dan Pembimbingan Warga Binaan Pemasyarakatan, dan juga telah memperhatikan hak Warga Binaan sesuai dengan Peraturan Pemerintah Republik Indonesia Nomor 32 Tahun 1999 Tentang Syarat dan Tata Cara Pelaksanaan Hak Warga Binaan.

Adapun faktor-faktor yang menghambat pelaksanaan pembinaan narapidana/residivis di Lembaga Pemasyarakatan Kelas II B Cilacap ialah sarana fisik terutama dalam hal kelebihan penghuni (over load). Faktor penghambat dibedakan ke dalam 2 yaitu faktor internal dan eksternal. Faktor internal ialah personil/aparat pembina Lembaga Pemasyarakatan, administrasi keuangan, dan sarana fisik. Sedangkan faktor eksternal ialah stigmatisasi masyarakat, sumber daya manusia, pemasaran hasil ketrampilan yang terbatas, dana, anggota masyarakat belum menerima kehadiran mantan narapidana di lingkungannya dan belum tersedia lapangan pekerjaan bagi bekas narapidana. Tidak adanya pembedaan dalam proses pembinaan narapidana dan residivis di dalam Lembaga Pemasyarakatan Kelas II B Cilacap juga menjadi salah satu faktor penyebab bertambahnya residivis. Berdasarkan beberapa hambatan yang di hadapi Lembaga Pemasyarakatan Kelas II B
Cilacap maka dari itu penulis berpandangan bahwa proses pembinaan terhadap narapidana belum berjalan maksimal/efektif.

\section{Saran}

Agar program pembinaan terhadap narapidana/residivis berjalan dengan baik, perlu ditingkatkan sumber daya manusia (SDM) petugas kemasyarakatan, serta penambahan tenaga ahli sehingga petugas memiliki bekal yang cukup dalam melakukan tugasnya, terutama yang berkaitan dengan kegiatan keterampilan serta sasaran tujuan lapas dapat tercapai.

Segera melengkapi sarana/prasarana yang belum ada ataupun yang rusak. Misalnya Membangun Kamar Hunian/Blok, menambahkan kamar mandi untuk para warga binaan, membeli peralatan pemotong presisi dan alat untuk membuat bingkai.

Agar pelatihan keterampilan yang dilakukan Lembaga Pemasyarakatan kelas II B Cilacap dapat berhasil dan berguna hendaknya lebih memperkuat kerjasama dengan instansi lain untuk memasarkan produk narapidana di Lapas. Memperbaiki kualitas bahan yang dipakai untuk membuat kerajinan juga diperlukan sehingga hasil karya yang dihasilkan dapat bersaing di pasaran dan tentunya dari segi nilai ekonomis lebih bisa untuk diperhitungkan.

\section{Daftar Pustaka}

Literatur

Abidin, Zainal. 2007. Hukum Pidana 1. Jakarta: Sinar Grafika.

Abdussalam \& DPM Sitompul. 2007. Sistem Peradilan Pidana. Jakarta: Restu Agung.

Ali, Zainuddin. 2006. Sosiologi Hukum. Jakarta: Sinar Grafika. 
Jurnal Media Komunikasi Pendidikan Pancasila dan Kewarganegaraan

Volume 2, Nomor 1 April 2020

Atmasasmita, Romli. 2010. Sistem Peradilan Pidana Kontemporer. Jakarta: Kencana Prenada Media Grup.

Chazawi, Adami. 2002. Pelajaran Hukum Pidana Bagian 2. Jakarta: Raja Grafindo Persada.

Hamzah, Andi. 1993. Sistem Pidana dan Pemidanaan di Indonesia. Jakarta: Pradnya Paramita.

Hakim, Abdul. 1986. Hukum Acara Pidana. Jakarta: Sarwoko.

Harsono, C. I. 1985. Sistem Baru Pembinaan Narapidana. Jakarta: DJAMBATAN.

Iswanto. 2013. Pengantar Ilmu Hukum. Purwokerto: Universitas Jenderal Soedirman.

Muladi. 1995. Kapita Selekta Sistem Peradilan Pidana. Semarang: Badan Penerbit Universitas Diponegoro

Muladi, dkk. 1995. Lembaga Pemasyarakatan dalam Prespektif Sistem Peradilan Pidana. Jakarta: Pustaka Sinar Harapan.

Pandjaitan, Petrus Irwan \& Wiwik Sri Widiarty. 2008. Pembaharuan Pemikiran Sahardjo Mengenai Pemasyarakatan Narapidana. Jakarta: INDHILL CO.

Prasetyo, Teguh. 2010. Hukum Pidana. Jakarta: Rajawali Pers.

Simorangkir, J. C. T. 2008. Kamus Hukum. Jakarta: Sinar Grafika.

Soemitro, Ronny Hanitiyo. 1982. Studi Hukum dan Masyarakat. Bandung: Alumni.

Soekanto, Soerjono. 1985. Efektifitas Hukum dan Peranan Sanksi. Jurnal
Ningtyas, Erina Suhestina. "Pelaksanaan Program Pembinaan Narapidana Pada Lembaga Pemasyarakatan Dalam rangka Pengembangan Sumber Daya Manusia". Jurnal Administrasi Publik. Vol 1, No. 6, Hal. 1266-1275.

Sulhin, Iqrak. "Filsafat (Sistem) Pemasyarakatan". Jurnal Kriminologi Indonesia. Vol 7, No. I Mei 2010 : 134-150, Hal. 139

Peraturan Perundang - Undangan

Undang-Undang Nomor 12 Tahun 1995 Tentang Pemasyarakatan.

Peraturan Pemerintah Republik Indonesia Nomor 31 Tahun 1999 Tentang Pembinaan dan Pembimbingan Warga Binaan Pemasyarakatan.

Peraturan Pemerintah Republik Indonesia Nomor 32 Tahun 2009 Tentang Syarat dan Tata Cara Pelaksanaan Hak Warga Binaan.

\section{Internet}

Surya, Nurmansyah Dwi. "Pengertian Sistem Peradilan Pidana". https://nurmansyahdwisurya.word press.com/2012/04/13/pengertiansistem-peradilan-pidana/, diakses pada 18 Oktober 2019 pukul 14.45 .

Yani, Dwi. "Definisi Arti Kejahatan". https://hukum-danumum.blogspot.com/artikel.html, diakses pada 27 September 2019 pukul 13.45.

"Kabupaten Cilacap". https://id.m.wikipedia.org.html, diakses pada 12 Desember pukul 17.32 . 